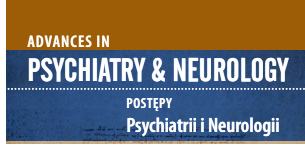

Correspondence to/

Adres do korespondencji:

Jan Bembenek

Zakład Neurofizjologii Klinicznej

Instytut Psychiatrii i Neurologii

ul. Sobieskiego 9

02-957 Warszawa

tel.: +48 224582617

fax: +48228424023

e-mail: jbembenek@ipin.edu.pl

Submitted/Otrzymano: 26.02.2020

Accepted/Przyjęto do druku: 25.04.2020

\title{
FACTORS INFLUENCING THE RESULT OF AN ELECTRONEUROGRAPHIC EXAMINATION
}

\section{CZYNNIKI WPŁYWAJĄCE NA WYNIK BADANIA ELEKTRONEUROGRAFICZNEGO}

\author{
Jan P. Bembenek \\ Department of Clinical Neurophysiology, Institute of Psychiatry and Neurology, \\ Warsaw, Poland \\ Zakład Neurofizjologii Klinicznej, Instytut Psychiatrii i Neurologii w Warszawie, \\ Warszawa, Polska
}

\begin{abstract}
Purpose: Author reviews up-to-date publications and provides comprehensive information on the most common pitfalls of electrodiagnostic tests. regarding commonly en-countered pitfalls in electrodiagnostic studies. The article presents also influence of devices settings, proper conditions of nerve conduction studies and factors that may affect their results.

Views: Electrodiagnostic tests, including electroneurographic (ENG) and electromyographic (EMG) examinations, are the gold standard in the evaluation of the function of peripheral nerves, neuromuscular junction and muscles. The main objective of these tests is to determine the type and location of the damage, but also to determine the characteristics of the various disorders associated with the peripheral nervous system. However, these tests should be considered as an extension and supplement of the patient's medical history, physical examination, results of other tests and should be always interpreted with the whole clinical picture. Many factors, such as biological, physical, resulting from the instrumentation used and their settings, and technical reasons may affect the result of electrodiagnostic tests or their incorrect interpretation. This may have serious consequences and lead to diagnostic errors.

Conclusions: Physicians should be aware of the electrodiagnostic pitfalls that may lead to erroneous conclusions about the nature of the abnormalities underlying peripheral nerve and muscle disorders. An incorrectly performed examination or its interpretation may affect further treatment or prevent the development of an accurate final diagnosis. In some cases, this may lead to delayed treatment introduction and worse patients outcome.
\end{abstract}

Key words: NCS, pitfalls, peripheral nerve conduction, neuromuscular disorders.

\section{Streszczenie}

Cel: W pracy dokonano przeglądu aktualnego piśmiennictwa i podano wyczerpujące informacje dotyczące najczęściej spotykanych pułapek w badaniach elektrodiagnostycznych. W artykule przedstawiono wpływ ustawień aparaturowych, warunki prawidłowego przeprowadzania badań elektroneurograficznych i czynniki, które mogą wpłynąć na ich wynik.

Poglądy: Badania elektrodiagnostyczne, w tym badania elektroneurograficzne (ENG) i elektromiograficzne (EMG), są złotym standardem w ocenie funkcji nerwów obwodowych, złącza nerwowo-mięśniowego i mięśni. Głównym celem tych badań jest określenie typu i lokalizacji uszkodzenia, ale także scharakteryzowanie zaburzeń związanych z obwodowym układem nerwowym. Należy je jednak traktować jako rozszerzenie i uzupełnienie wywiadu chorobowego, badania fizykalnego i pozostałych badań dodatkowych. Zawsze powinny być interpretowane z uwzględnieniem całego obrazu klinicznego. Istnieje wiele czynników, takich jak biologiczne, fizyczne, wynikające z ustawień aparaturowych i używanego oprzyrządowania przyczyny techniczne, które mogą wpłynąć na wynik badań elektrodiagnostycznych lub ich nieprawidłową interpretację. Może to prowadzić do poważnych konsekwencji, w tym błędów diagnostycznych.

Wnioski: Lekarze powinni zdawać sobie sprawę z pułapek związanych z elektrodiagnostyką, które mogą prowadzić do błędnych wniosków dotyczących charakteru zmian leżących u podstaw zaburzeń nerwów obwodowych i mięśni u ich pacjentów. Nieprawidłowo przeprowadzone badanie lub jego interpretacja mogą wpłynąć na dalsze postępowanie z chorym lub brak ostatecznej diagnozy. W niektórych przypadkach może to prowadzić do opóźnienia włączenia leczenia i gorszego rokowania chorych.

Słowa kluczowe: ENG, pułapki, przewodzenie w nerwach obwodowych, choroby nerwowo-mięśniowe. 
Factors influencing the result of an electroneurographic examination

Czynniki wpływające na wynik badania elektroneurograficznego

\section{INTRODUCTION}

Electroneurography (ENG), also often known as nerve conduction study, is part of the neurophysiological examination of the peripheral nervous system and is often supplemented by electromyographic examination (EMG) with a needle electrode. These tests are commonly used in the diagnosis of neuromuscular disorders, allowing for the assessment of the functional status of muscles and nerves.

The motor conduction evaluation is based on applying electric impulses to the skin (over the course of the nerve), causing a depolarizing square wave in the peripheral nerve and recording the response from the relevant innervated muscle. Such a response is called compound muscle action potential (CMAP) and can be recorded with surface electrodes or needle monopolar electrodes placed close to the nerve, especially in case of difficult access by surface electrodes (e.g. stimulation of the sciatic nerve under the buttock, where the nerve is deeply located). Currently, surface electrodes are much more frequently used; they record the time it takes for the fastest axons to conduct the impulse to the muscle, exceed the neuromuscular junction, and depolarize the muscle membrane; they also measure the size of the response.

The ENG of sensory fibres is technically more difficult due to small amplitudes (they range from few to a few dozens of microvolts, compared to muscle potentials recorded during the stimulation of motor fibres, which range from few to a few dozen millivolts). Surface electrodes are placed over the examined nerve, or alternatively needle-type electrodes can be used. Rectangular electric impulses of 0.1 to $0.2 \mathrm{~ms}$ duration and super maximum intensity (exceeding by $20-30 \%$ the intensity causing the maximum sensory response - nerve action potential, SNAP) are used for the stimulation, similarly to the motor fibre examinations. This allows ENG to determine the type of damage (the motor and sensory fibres), besides the distribution and location of changes (distal, proximal, nerve pressure, nerve continuity interruption, etc.) [1].

Patients with various complaints are more and more often referred to ENG tests, which is associated with a belief that these tests are objective and the results are highly repeatable. When performed properly technically, ENG is actually an objective and reproducible method of assessing the functional state of nerves and muscles. However, it should be stressed that many factors may influence the results, which may in turn influence decisions on further diagnostic and therapeutic procedures. The correct interpretation of the results of the electrodiagnostic tests is also extremely important. It requires specialist knowledge and experience as well as a detailed knowledge of the anatomy of the nervous system $[1,2]$.

\section{WPROWADZENIE}

Elektroneurografia (electroneurography - ENG), nazywana też badaniem przewodnictwa nerwowego, jest częścią badania neurofizjologicznego obwodowego układu nerwowego i zwykle jest uzupełniana o badanie elektromiograficzne elektrodą igłową (electromyography - EMG). Badania te są powszechnie stosowane $\mathrm{w}$ diagnostyce chorób nerwowo-mięśniowych. Pozwalają na ocenę stanu czynnościowego mięśni i nerwów.

Badanie przewodnictwa ruchowego polega na zastosowaniu na skórę (nad przebiegiem nerwu) impulsów elektrycznych powodujących powstanie kwadratowej fali depolaryzacyjnej w nerwie obwodowym oraz odbiór odpowiedzi $\mathrm{z}$ odpowiedniego mięśnia unerwianego. Odpowiedź ta jest określana jako złożony mięśniowy potencjał czynnościowy (compound muscle action potential - CMAP). Odpowiedzi te można zarejestrować za pomocą elektrod powierzchniowych lub igłowych elektrod monopolarnych umieszczanych w pobliżu nerwu, szczególnie w przypadku utrudnionego dostępu elektrodami powierzchniowymi (np. stymulacja nerwu kulszowego pod pośladkiem, gdzie nerw jest głęboko położony). Obecnie zdecydowanie częściej stosowane są elektrody powierzchniowe, które rejestrują czas potrzebny najszybszym aksonom na przewodzenie impulsu do mięśnia, przekroczenie styku nerwowo-mięśniowego i depolaryzację błony mięśniowej, a także wielkość odpowiedzi.

Badanie ENG włókien czuciowych jest trudniejsze technicznie ze względu na niskie amplitudy odpowiedzi (rzędu kilku- lub kilkudziesięciu mikrowoltów, w porównaniu z potencjałami mięśniowymi rejestrowanymi przy stymulacji włókien ruchowych, których wielkość jest rzędu kilku- lub kilkudziesięciu miliwoltów). Elektrody powierzchniowe są umieszczane nad badanym nerwem. Istnieje także możliwość zastosowania elektrod odbiorczych igłowych. Do stymulacji, podobnie jak w badaniu włókien ruchowych, stosuje się prostokątne impulsy elektryczne o czasie trwania $0,1-0,2$ ms i supramaksymalnym natężeniu [przekraczające o $20-30 \%$ natężenie powodujące maksymalną odpowiedź czuciową (sensory nerve action potential - SNAP)]. Dzięki temu ENG pozwala różnicować rodzaj uszkodzenia (zajęcie włókien ruchowych, czuciowych) oraz określić rozkład i miejsce zmian (dystalne, proksymalne, ucisk nerwu, przerwanie ciągłości nerwu itp.) [1].

Pacjenci z różnymi dolegliwościami są coraz częściej kierowani przez lekarzy na badanie ENG. Istnieje przekonanie, że jest to badanie obiektywne, a jego wyniki są wysoce powtarzalne. Prawidłowo technicznie wykonane, badanie to stanowi faktycznie obiektywną i powtarzalną metodę oceny stanu czynnościowego nerwów i mięśni. Należy jednak pamiętać, że wiele czynników może wpłynąć na jego wynik i tym samym na decyzje odnośnie do dalszego postępowania diagnostycznego i terapeutycznego. Niezwykle istotna jest także prawidłowa interpretacja otrzymanych wyników badań elektrodiagnostycznych, co wymaga posiadania specjalistycznej wiedzy i doświadczenia oraz znajomości anatomii układu nerwowego $[1,2]$. 
In order to optimize the sensitivity of the measurements made during electrodiagnostic tests, all variables that may affect the results must be considered. These are: device settings, location of electrodes (registration method), type of electrodes, biological (age, height, sex, skin thickness) and physical factors (position of the limb, muscle length, temperature and length of the nerve section) $[2,3]$. Based on a review of the PubMed database and the latest guidelines for ENG tests (published in the last two years), as well as several internationally recognized textbooks, the author presents below the factors that affect ENG examinations and the interpretation of their results.

\section{Device settings}

At the beginning of 2020, detailed recommendations for setting up and calibrating EMG instruments, additional accessories used for testing, safety principles during EMG examination, software, data storage, interference and artifact handling were published. The aim of these recommendations is to standardize the tests performed on different instruments and in different centres to ensure that they are repeatable and comparable [3].

Professionals who perform these tests should be aware that the accuracy of the diagnosis may depend on the amplifier settings. For example, a higher sensitivity of the amplifier will reduce the response latency. This may be important, for example, in tests for carpal tunnel syndrome (CTS), in which the prolonged distal latency in the motor fibres of the median nerve is one of the diagnostic criteria [4].

Biological signals may be expressed as the sum of simple oscillatory functions (e.g. sines and cosines) whose individual phases and amplitudes are summed or cancelled and in this way form a characteristic waveform. A filter is an electronic device that removes frequency components from a waveform in response to nerve stimulation. A high frequency filter removes higher frequencies, leaving lower frequencies, and is therefore commonly called low pass. Similarly, a low frequency filter removes lower frequencies, allowing only high frequencies to be recorded and this is called high pass. The recommended cut-off of low frequency for ENG is $2-20 \mathrm{~Hz}$, whereas the cut-off of high frequencies for SNAP nerve sensory action potentials and $\mathrm{M}$ responses is 2000 and $10000 \mathrm{~Hz}$ respectively [5]. Increased cut-off of low frequencies will result in lower SNAP and M responses by about $15 \%$ in amplitude and $25 \%$ in surface area, as well as being approximately $8 \%$ shorter in duration. This will affect CMAP more than SNAP [6]. Lowering the high frequency cut-off will result in both SNAP and CMAP responses having lower amplitudes, delayed peak/onset latencies, and extended
Aby zoptymalizować czułość pomiarów dokonanych w trakcie badań elektrodiagnostycznych, należy wziąć pod uwagę wszystkie zmienne, które mogą wpływać na wyniki. Istotne dla pomiarów przewodnictwa nerwowego są: ustawienia aparatu, umieszczenie elektrod (metoda rejestracji), rodzaj elektrod, czynniki biologiczne (wiek badanego, wzrost, płeć, grubość skóry) oraz fizyczne (pozycja kończyny, długość miesśnia, temperatura i długość odcinka nerwu) $[2,3]$. Autor na podstawie przeglądu bazy PubMed, najnowszych wytycznych (opublikowanych w ciągu ostatnich dwóch lat) dotyczących badań ENG i powszechnie uznanych podręczników autorów zagranicznych przedstawia czynniki wpływające na badanie ENG oraz interpretację jego wyników.

\section{Ustawienia aparatu}

Na początku 2020 roku ukazały się szczegółowe zalecenia dotyczące ustawień i kalibracji aparatów do EMG, dodatkowych akcesoriów używanych do badań, zasad bezpieczeństwa $\mathrm{w}$ trakcie badań EMG, oprogramowania, przechowywania danych oraz postępowania $\mathrm{w}$ przypadku zakłóceń i artefaktów. Mają one na celu standaryzację badań wykonywanych w różnych ośrodkach i na różnych aparatach, tak aby były one powtarzalne i porównywalne [3].

Osoby wykonujące badanie powinny zdawać sobie sprawę, że czułość diagnozy może zależeć od ustawień wzmacniacza. Na przykład większa czułość wzmacniacza spowoduje skrócenie latencji odpowiedzi. Może to być istotne chociażby w badaniach w kierunku zespołu cieśni nadgarstka (ZCN), w którym wydłużona latencja końcowa we włóknach ruchowych nerwu pośrodkowego jest jednym z kryteriów rozpoznania tego schorzenia [4].

Sygnały biologiczne mogą być wyrażone jako suma zestawu prostych funkcji oscylacyjnych (np. sinusów i cosinusów), których poszczególne fazy i amplitudy sumują się lub anulują i tworzą charakterystyczny kształt fali. Filtr jest urząazeniem elektronicznym, które usuwa komponenty o określonych częstotliwościach z zapisu fali, będącej odpowiedzią na stymulację nerwu. Filtr wysokiej częstotliwości usuwa wyższe częstotliwości, pozostawiając niższe, a zatem jest powszechnie nazywany dolnoprzepustowym. Podobnie filtr niskiej częstotliwości usuwa niższe częstotliwości, pozwalając na zapis tylko wysokich, i jest nazywany górnoprzepustowym. Zalecane odcięcie niskiej częstotliwości dla ENG wynosi 2-20 Hz, podczas gdy odcięcia wysokiej częstotliwości dla czuciowych potencjałów czynnościowych nerwów SNAP i odpowiedzi M wynoszą odpowiednio 2000 i $10000 \mathrm{~Hz}$ [5]. Podniesienie odcięcia niskich częstotliwości spowoduje, że zarówno SNAP, jak i odpowiedzi M będą miały mniejszą o ok. 15\% amplitudę i o $25 \%$ pole powierzchni oraz krótszy o ok. $8 \%$ czas trwania. Wpłynie to bardziej na CMAP niż SNAP [6]. Obniżenie odcięcia wysokich częstotliwości spowoduje, że zarówno SNAP, jak i odpowiedzi M będą miały mniejsze amplitudy, opóźnione szczytowe/początkowe latencje 
duration. In this case, it will affect SNAP more than M responses [5].

The aim of recording systems in EMG devices is to accurately reproduce physiological signals generated in peripheral nerves, but unfortunately the presence of artifacts seems unavoidable. The authors of the above-mentioned recommendations [3] have classified the technical factors that may be the source of artifacts influencing the examination:

- the cable motion artefact;

- transducer noise caused by the movements in the gelskin interface, including changes related to skin stretching;

- high skin-electrode impedance (hence the need to wipe with a gauze soaked in spirit before sticking the electrodes);

- interference from the EMG apparatus (e.g. from semiconductors in amplifiers);

- biomedical devices (e.g. pacemakers).

It is important to make every effort to reduce artifacts and improve the quality of recording. It is recommended to disconnect the electrical circuit of the EMG apparatus from those used for other electrical devices. Switch-off unnecessary electrical devices and lights in the exam room. Do not use fluorescent lamps or light dimmers (they emit high frequency pulses). For surface electrode conduction tests, the skin should be cleaned with sandpaper, abrasive gel or $70 \%$ alcohol to reduce impedance [3].

\section{Size of the recording electrode}

When using larger recording electrodes stuck to the skin, we obtain CMAPs with slightly smaller amplitudes, field and slower conduction velocities, but without clinically significant changes in latency or duration of negative phase [7]. Ven et al. demonstrated also that the SNAP amplitudes recorded were smaller with increasing the area of the recording surface electrodes [8]. At present, the use of surface electrodes with a diameter of $10 \mathrm{~mm}$ is preferred and $20-40 \mathrm{~mm}$ electrodes are not recommended [2].

\section{Reduction of electrical artifacts}

If the distance between the stimulating and recording electrodes is too short, this can lead to the creation of artifacts that distort the recorded signal. The stimulus artifact can be reduced in the following way:

- reducing skin impedance, by rubbing the epidermis under the stimulating electrode;

- keeping the skin dry between and under the stimulation and recording electrodes;

- changing the position of the patient's grounding electrode (it should be located between the stimulating and the receiving electrodes); i wydłużony czas trwania. W tym przypadku wpłynie to bardziej na SNAP niż odpowiedzi M [5].

Celem systemów rejestrujących w aparatach EMG jest dokładne odtworzenie sygnałów fizjologicznych generowanych w nerwach obwodowych, niestety jednak obecność artefaktów wydaje się nieunikniona. Autorzy wspomnianych już zaleceń [3] do czynników technicznych mogących być źródłem artefaktów mających wpływ na badanie zaliczyli:

- artefakt ruchu kabla,

- szum przetwornika spowodowany przemieszczeniami w interfejsie żel-skóra, w tym zmiany związane $\mathrm{z}$ rozciąganiem skóry,

- wysoką impedancję na styku elektrody i skóry (stąd konieczne przetarcie gazikiem nasączonym spirytusem przed naklejeniem elektrod),

- zakłócenia z aparatu EMG (np. z półprzewodników we wzmacniaczach),

- urządzenia biomedyczne (np. rozrusznik serca).

Ważne jest, aby podjąć szereg wysiłków mających na celu redukcję artefaktów i poprawę jakości rejestracji. Zalecane jest odłączenie obwodu elektrycznego aparatu EMG od tych używanych dla innych urządzeń elektrycznych. Należy wyłączyć niepotrzebne urządzenia elektryczne i światła znajdujące się w pomieszczeniu, w którym odbywa się badanie. Nie powinno się używać świetlówek i ściemniaczy światła (emitują impulsy o wysokiej częstotliwości). W przypadku badań przewodzenia elektrodami powierzchniowymi skóra powinna być oczyszczona za pomocą papieru ściernego, żelu ściernego lub 70\% alkoholu w celu zmniejszenia impedancji [3].

\section{Wielkość elekłrody odbiorczej}

Używając większych elektrod rejestrujących przyklejanych na skórę, otrzymuje się odpowiedzi $\mathrm{M}$ o nieco mniejszych amplitudach i polu powierzchni oraz wolniejszych prędkościach przewodzenia, ale bez klinicznie znaczących zmian w latencji lub czasie trwania wychylenia ujemnego załamka [7]. Ven i wsp. wykazali, że także rejestrowane amplitudy SNAP były mniejsze wraz ze wzrostem powierzchni elektrod rejestrujących [8]. Aktualnie preferowane jest stosowanie elektrod powierzchniowych o średnicy $10 \mathrm{~mm}$, a nie jest zalecane stosowanie elektrod o średnicy 20-40 mm [2].

\section{Redukcja artefaktów elektrycznych}

Jeśli odległość między elektrodami stymulującą i rejestrującą jest zbyt mała, może to prowadzić do powstania artefaktów powodujących zniekształcenie zarejestrowanego sygnału. Artefakt bodźca można zmniejszyć przez:

- zmniejszenie impedancji skóry wskutek starcia naskórka pod elektrodą stymulującą,

- utrzymanie suchej skóry między elektrodami stymulującymi i rejestrującymi oraz pod nimi,

- zmianę położenia elektrody uziemiającej pacjenta (powinna znajdować się pomiędzy elektrodami stymulującą i odbiorczą), 
- rotating the anode while the cathode is held over the nerve;

- using a two-phase stimulation pulse, which is available in many EMG devices [2].

\section{Too-small electrical stimulus}

If the electrical stimulus used is too small and there is no depolarization in all active nerve fibres, the CMAP response is incomplete.

An example of an incomplete response expressed by a small CMAP amplitude when an electrical stimulus is too small is presented in Figures 1 and 2.

For example, this problem may be encountered during the stimulation of deep nerves that are difficult to reach in examination, such as the lateral cutaneous nerve of the thigh stimulated over the upper anterior iliac spine, especially in obese people, and also during stimulation at the Erb's point, in the popliteal fossa, in an attempt to stimulate the tibial nerve and the sciatic nerve below the buttock. In the case of examination of the lateral cutaneous and sciatic nerves, the use of monopolar needle electrodes may be an effective method to eliminate these problems, but also, especially in the case of the sciatic nerve, an examination under ultrasound control may be helpful. Moreover, if the nerve stimulation in the proximal segment (often located deeper and more difficult to access for stimulation) is not maximal, an apparent conduction block can be observed. On the other hand, too high electrical stimulus can cause excessive current dispersion and stimulation of adjacent nerves (particularly important when using surface electrodes, which can also record responses from adjacent muscles supplied by other nerves than the tested one) $[1,9]$.
- obracanie anody, podczas gdy katoda jest utrzymywana nad nerwem,

- użycie dwufazowego impulsu stymulacyjnego dostępnego w wielu urządzeniach EMG [2].

\section{Zbył mały bodziec elekłryczny}

Jeżeli zastosowany bodziec elektryczny jest zbyt mały i nie dochodzi do depolaryzacji we wszystkich czynnych włóknach nerwu, uzyskana odpowiedź CMAP jest niepełna.

Przykład niepełnej odpowiedzi wyrażonej małą amplitudą odpowiedzi przy zastosowaniu zbyt małego bodźca elektrycznego zaprezentowano na rycinach 1 i 2.

$\mathrm{Z}$ takim problemem możemy mieć do czynienia np. podczas stymulacji nerwów głęboko położonych i trudno dostępnych badaniu, takich jak nerw skórny boczny uda stymulowany w okolicy kolca biodrowego przedniego górnego, szczególnie u osób otyłych, a także podczas stymulacji w punkcie Erba, w dole podkolanowym podczas próby stymulacji nerwu piszczelowego oraz nerwu kulszowego poniżej pośladka. W przypadku badania nerwów skórnych bocznych i kulszowych skuteczną metodą eliminacji tego typu problemów może być użycie monopolarnych elektrod igłowych, ale również, szczególnie w przypadku nerwu kulszowego, pomocne może być wykonanie badania pod kontrolą ultrasonograficzną. Ponadto, jeśli pobudzenie nerwu w odcinku proksymalnym (często głębiej położonym i trudniej dostępnym stymulacji) nie jest maksymalne, można obserwować pozorny blok przewodzenia! Z drugiej jednak strony zbyt duży bodziec elektryczny może spowodować nadmierne rozproszenie prądu i stymulację sąsiednich nerwów (szczególnie istotne w przypadku stosowania elektrod odbiorczych powierzchniowych, które mogą rejestrować odpowiedzi również z sąsiednich mięśni zaopatrywanych przez inne nerwy niż badany) $[1,9]$.

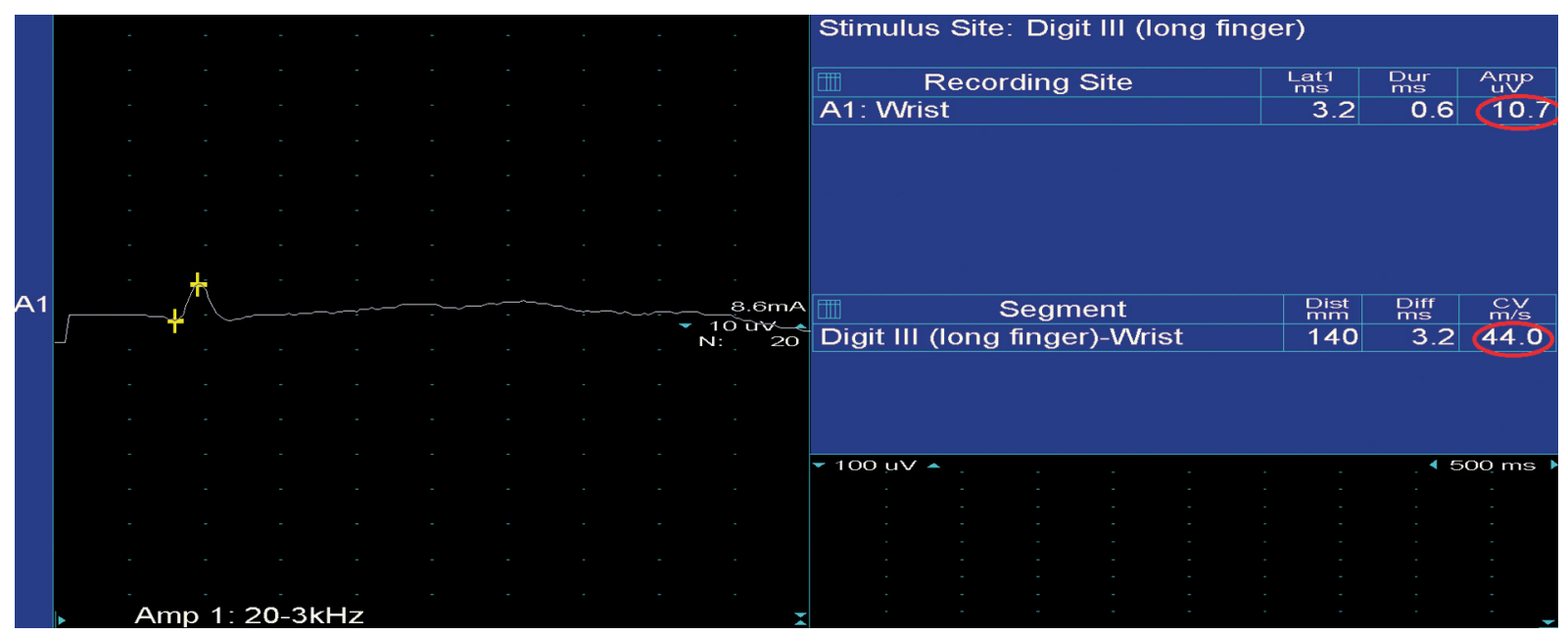

Figure 1. Incomplete response (amplitude $10.7 \mu \mathrm{V}$ ) and the borderline conduction velocity (44 m/s) after applying a stimulus of $8.6 \mathrm{~mA}$ during stimulation of the median nerve sensory fibres

Rycina 1. Niepełna odpowiedź (amplituda 10,7 $\mu \mathrm{V}$ ) i graniczna szybkość przewodzenia (44 m/s) po zastosowaniu bodźca 8,6 mA w trakcie stymulacji włókien czuciowych nerwu pośrodkowego 
Factors influencing the result of an electroneurographic examination

Czynniki wpływajace na wynik badania elektroneurograficznego

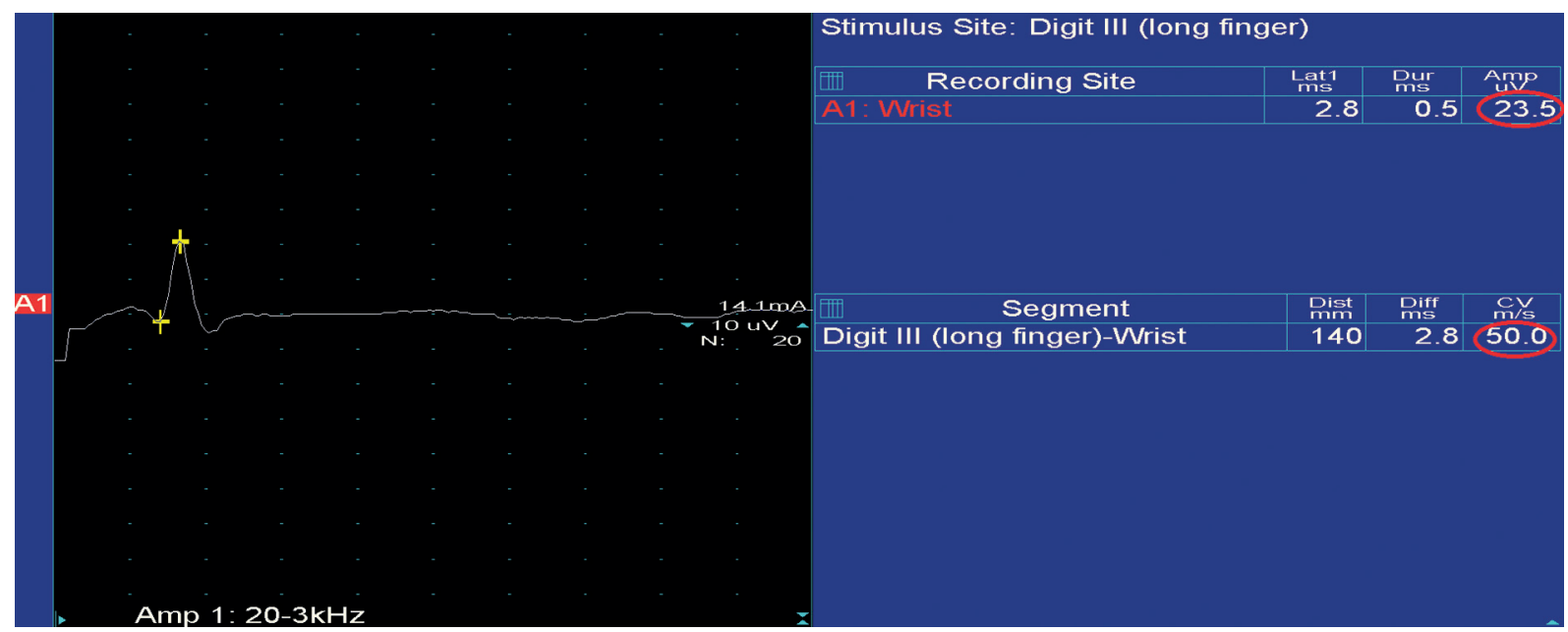

Figure 2. Clear improvement in response amplitude $(23.5 \mu \mathrm{V})$ and normal conduction velocity $(50 \mathrm{~m} / \mathrm{s})$ after using $14.1 \mathrm{~mA}$ stimulus in the same patient

Rycina 2. Wyraźna poprawa w zakresie amplitudy odpowiedzi $(23,5 \mu \mathrm{V})$ i prawidłowa szybkość przewodzenia (50 m/s) po zastosowaniu bodźca 14,1 mA u tego samego pacjenta

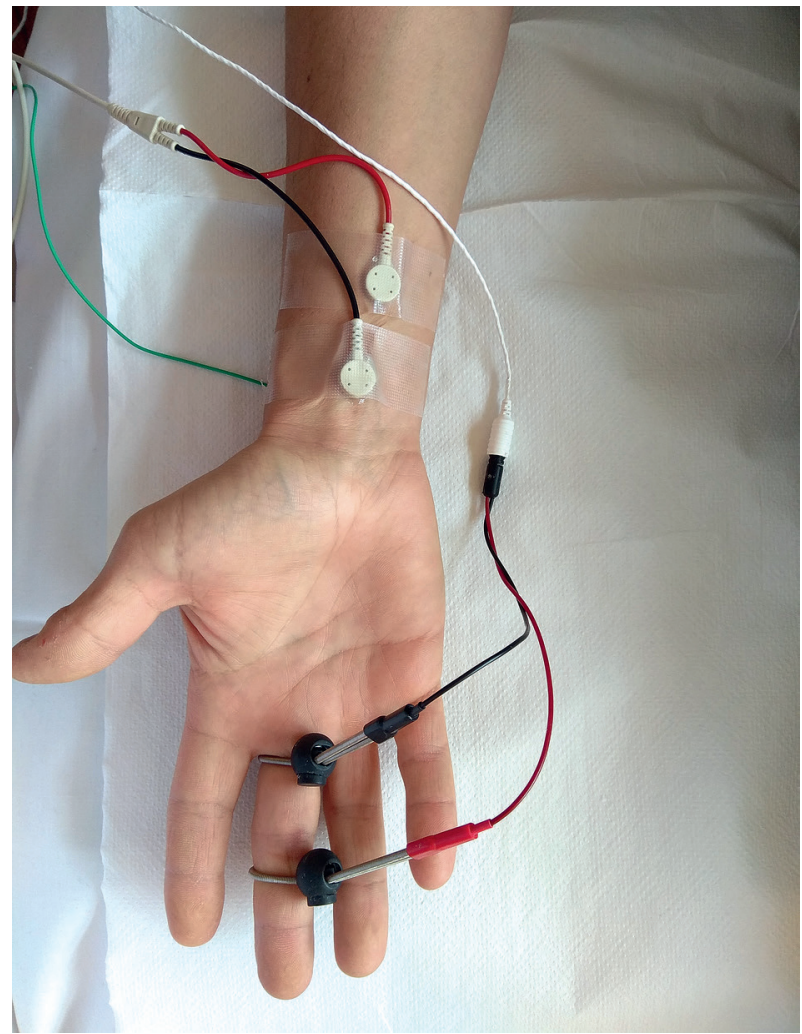

Figure 3. Methodology of conduction recording in the sensory fibres of the median nerve using the orthodromic method. Stimulation ring electrodes are placed on the middle finger. The receiving electrodes are placed over skin proximally to the wrist

Rycina 3. Rejestracja przewodzenia we włóknach czuciowych nerwu pośrodkowego metodą ortodromową. Elektrody stymulacyjne obrączkowe sq̨ umieszczone na palcu środkowym. Elektrody odbiorcze sq naklejone na skórze proksymalnie w stosunku do stawu promieniowo-nadgarstkowego

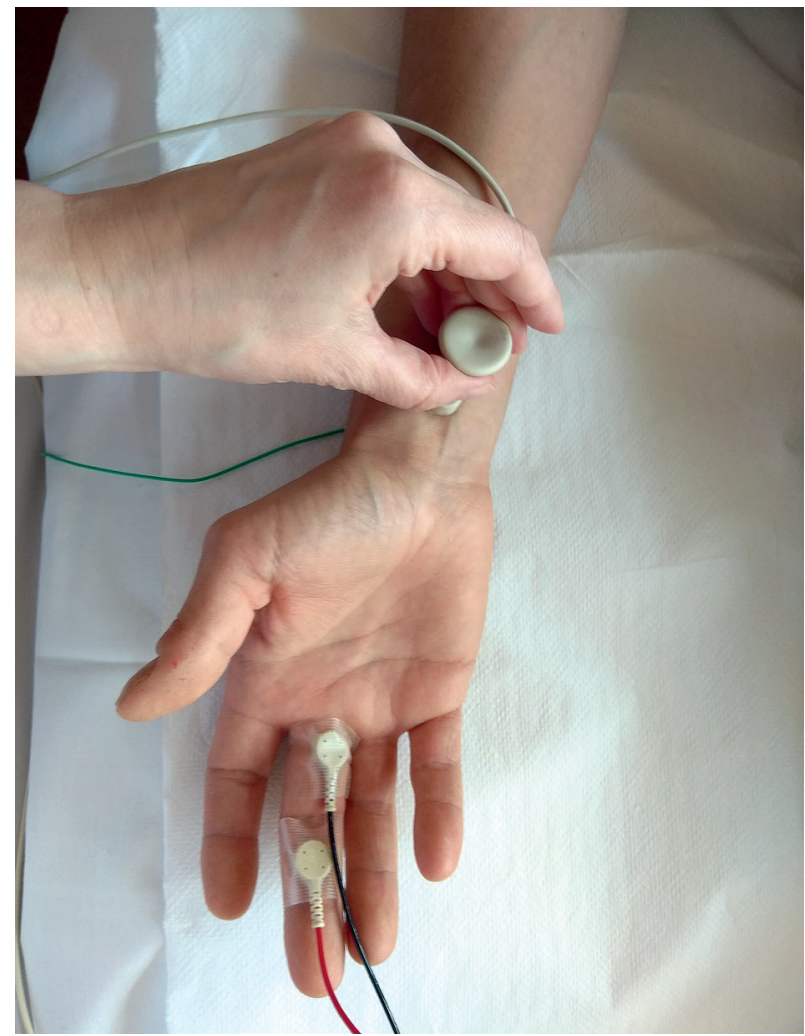

Figure 4. Methodology of the conduction recording in the sensory fibres of median nerve with the antidromic technique. The stimulation electrode is placed proximally to the radial wrist joint; the recording electrodes are placed on the skin of the middle finger

Rycina 4. Rejestracja przewodzenia we włóknach czuciowych nerwu pośrodkowego metodą antydromową. Elektroda stymulacyjna jest umieszczona proksymalnie w stosunku do stawu promieniowo-nadgarstkowego. Elektrody odbiorcze sq̨ naklejone na skórze palca środkowego 


\section{Orthodromic vs. antidromic technique}

The measurement of the response of sensory nerves conducted in a physiological way, i.e. from the peripheral to the central direction, is orthodromic conduction. Another way is to measure the response conducted in the opposite direction (from proximal segments to the distal direction), which is the antidromic technique.

Examples of stimulation of median nerve sensory fibres and the orthodromic and antidromic recording methods are presented in Figures 3 and 4.

In the case of antidromic stimulation, the responses recorded by the surface electrode are usually larger (the nerve is located closer to the surface of the skin at the point of response recording). The conduction times are similar with both measurement methods. The main disadvantage of the antidromic technique is the fact that responses from sensory fibres are usually disturbed by motor artifacts, which is caused by muscle contraction due to additional stimulation of motor fibres (most nerves contain both sensory and motor fibres). As a result, the amplitude of responses from the sensory fibres is much larger. Hence, antidromic stimulation may be used, provided that the applied stimuli are smaller than those necessary to stimulate the motor fibres $[10,11]$.

An example of the difference in ortho- and antidromic responses recorded is presented in Figures 5 and 6.

\section{Nerve length measurements}

A flexible (but not stretchable) tape is necessary to accurately measure the length of the nerve. Some measurements may be affected by flexion/hyperexten-

\section{Metoda ortodromowa versus antydromowa}

Odpowiedź przewodzona w nerwach czuciowych w sposób fizjologiczny, czyli od obwodu w kierunku ośrodkowym, to przewodzenie ortodromowe. Odpowiedź przewodzona w kierunku odwrotnym, tj. od odcinków proksymalnych w kierunku dystalnym, to przewodzenie antydromowe.

Przykłady stymulacji włókien czuciowych nerwu pośrodkowego oraz metoda rejestracji ortodromowa i antydromowa zostały przedstawione na rycinach 3 i 4 .

W przypadku stymulacji antydromowej odpowiedzi rejestrowane elektrodą powierzchniową są zwykle większe (w miejscu rejestracji odpowiedzi nerw przebiega bardziej powierzchownie). Obie metody pomiarów dają zbliżone czasy przewodzenia. Główną wadą metody antydromowej jest to, że odpowiedzi z włókien czuciowych są zwykle zakłócone przez artefakty ruchowe, co jest spowodowane skurczem mięśni ze względu na stymulację dodatkowo włókien ruchowych (większość nerwów zawiera zarówno włókna czuciowe, jak i ruchowe). W efekcie amplituda odpowiedzi z włókien czuciowych jest znacznie większa. Dlatego stymulacja antydromowa może być stosowana pod warunkiem, że zastosowane bodźce będą mniejsze niż konieczne do stymulacji włókien ruchowych $[10,11]$.

Przykład różnicy w zarejestrowanej odpowiedzi z użyciem rejestracji metodą ortodromową i antydromową przedstawiono na rycinach 5 i 6 .

\section{Pomiary długości nerwu}

Elastyczna (ale nie rozciągliwa) taśma jest niezbędna, aby dokonać dokładnego pomiaru długości na przebiegu nerwu. Na niektóre pomiary może wpływać zgięcie lub

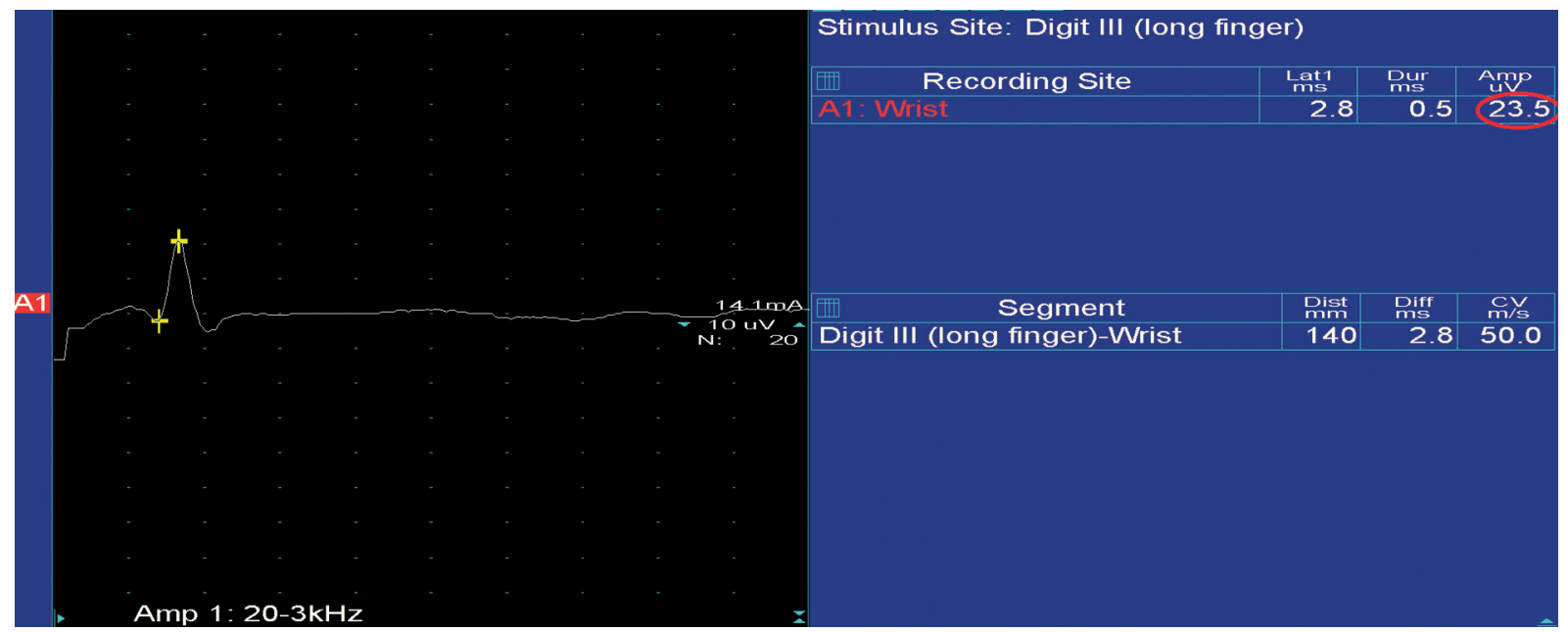

Figure 5. Significantly lower amplitude $(23.5 \mu \mathrm{V})$ of the response to stimulation of median nerve sensory fibres using the orthodromic technique

Rycina 5. Znacznie mniejsza amplituda odpowiedzi $(23,5 \mu \mathrm{V})$ na stymulację włókien czuciowych nerwu pośrodkowego przy zastosowaniu rejestracji metodą ortodromową 


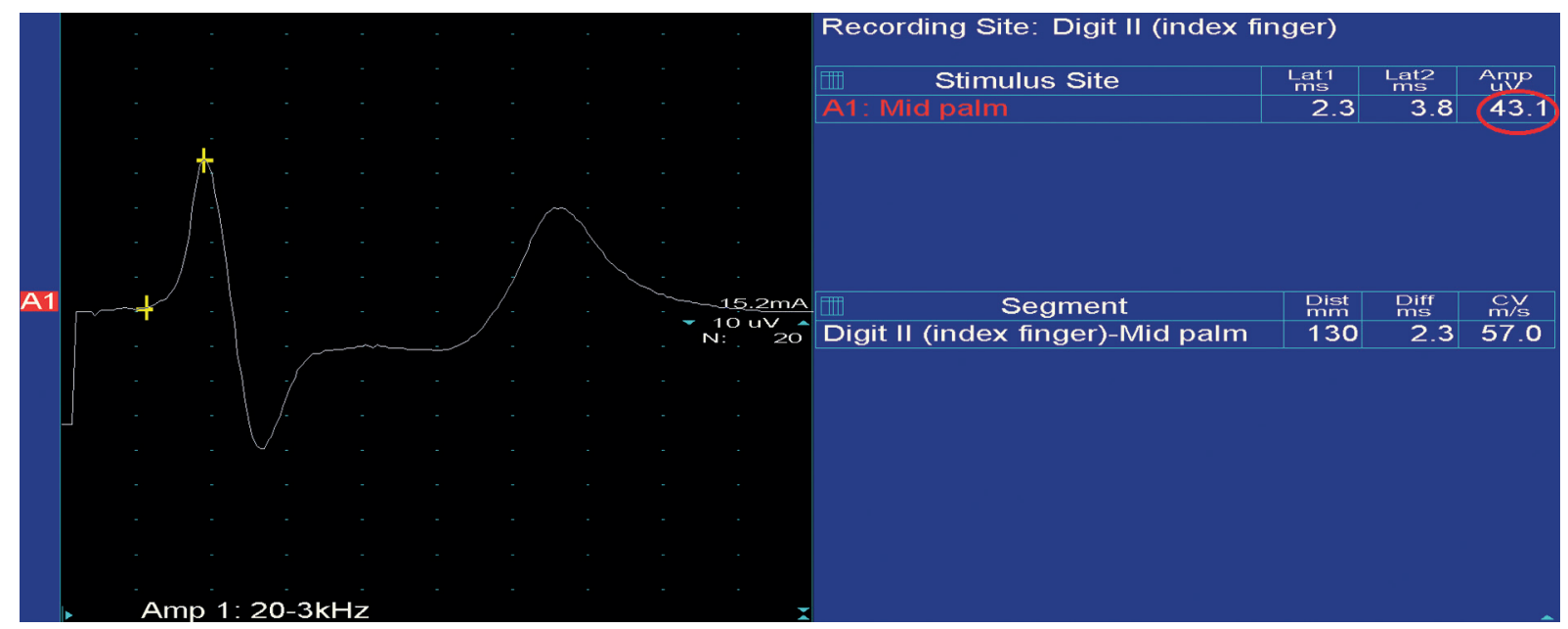

Figure 6. Significantly higher amplitude $(43.1 \mu \mathrm{V})$ of the response to stimulation of the median nerve sensory fibres using the antidromic technique

Rycina 6. Znacznie większa amplituda odpowiedzi $(43,1 \mu \mathrm{V})$ na stymulację włókien czuciowych nerwu pośrodkowego przy zastosowaniu rejestracji metodą antydromowa

sion around the joint. For example, the smallest errors occur in the ulnar nerve if the limb is bent at $90-135^{\circ}$. The length of the nerve can be measured with an accuracy of 2-8 $\mathrm{mm}$, which corresponds to a measurement error of $3-5 \%[1,2]$. A cause of erroneous measurements may also be the movement of the ulnar nerve from the place of its typical course, especially when the result of an imaging test with dynamic evaluation is not available (e.g. ultrasound). It should be noted that the dynamic assessment of the nerve subluxation above the groove (occurring asymptomatically in about $20 \%$ of the population) may indicate a predisposition to slow nerve damage. Therefore, ultrasound examination is a valuable supplement in the diagnostic process, allowing for the assessment of the predisposition to abnormal nerve course [12].

\section{Gender}

In the majority of studies, no effect of gender on the nerve conduction velocity was observed [13]. SNAP amplitudes in men are lower than in women, both in the antidromic (direction of nerve conduction from the body of the nerve cell to the synapse) [14] and orthodromic (direction of nerve conduction from the synapse to the body of the nerve cell) [13], which may result from the larger circumference of fingers and thicker epidermis in men.

\section{Height}

In taller people, conduction velocities are slower than in short people [15]. The conduction velocity decreases in nerves in lower limbs by $2-3 \mathrm{~m} / \mathrm{s}$ for each $10 \mathrm{~cm}$ of height [15]. przeprost w okolicach stawu. Na przykład najmniejsze błędy występują w nerwie łokciowym, jeśli kończyna jest zgięta pod kątem $90-135^{\circ}$. Długość odcinka nerwu można zmierzyć z dokładnością 2-8 mm, co odpowiada błędowi w pomiarze odległości 3-5\% [1,2]. Przyczyną błędnych pomiarów może być także przemieszczanie się nerwu łokciowego z miejsca typowego przebiegu w rowku tego nerwu, zwłaszcza gdy niedostępny jest wynik badania obrazowego $\mathrm{z}$ oceną dynamiczną (np. badanie ultrasonograficzne - USG). Należy zauważyć, że dynamiczna ocena podwichnięcia nerwu nad rowkiem (występująca bezobjawowo u ok. $20 \%$ populacji) może wskazywać na predyspozycję do powolnego uszkodzenia nerwu. Dlatego cennym uzupełnieniem $\mathrm{w}$ trakcie diagnostyki, pozwalającym na ocenę predyspozycji do nieprawidłowego przebiegu nerwu, jest badanie USG [12].

\section{Płeć}

W większości badań nie stwierdzono wpływu płci na szybkość przewodzenia w nerwach [13]. Amplitudy SNAP u mężczyzn są mniejsze niż u kobiet zarówno w badaniach metodą antydromową (kierunek przewodzenia w nerwie od ciała komórki nerwowej do synapsy) [14], jak i ortodromową (kierunek przewodzenia od synapsy do ciała komórki nerwowej) [13], co może wynikać $\mathrm{z}$ większego obwodu palców i grubszego naskórka u mężczyzn.

\section{Wzrost}

U wyższych osób szybkości przewodzenia są wolniejsze niż u niskich [15]. Szybkość przewodzenia zmniejsza się w nerwach kończyn dolnych o 2-3 m/s na każde $10 \mathrm{~cm}$ wzrostu [15]. 
The SNAP amplitude is also inversely proportional to height [13].

\section{Skin thickness}

Skin thickness is inversely correlated with the size of the SNAP response [16]. In patients with a thicker epidermis, smaller SNAP amplitudes are recorded. Therefore, partial epidermis abrasion is necessary, e.g. in people performing hard physical work on a daily basis. Special abrasive papers are available for this purpose.

\section{Age}

In children the nerve conduction velocity is lower. Adult values are already reached in teenagers. From the age of 20 , the nerve conduction velocity decreases with age: $0.5-1.8 \mathrm{~m} / \mathrm{s}$ for every 10 years $[15,17]$. The decrease is more prominent in the lower than in the upper limbs [15]. In adults, the decrease in SNAP amplitude progressing with age has been well documented due to loss of sensory fibres and increased dispersion of conduction in sensory nerves. The duration of SNAP is also prolonged [2].

The latency of responses in the sensory and motor fibres has not been demonstrated to change with age [15].

\section{Temperature}

Temperature affects measurements of nerve conduction velocity and response rate. It affects the CMAP size, SNAP responses and conduction velocity. The amplitude of CMAP increases by $1.7 \%$ per every $1^{\circ} \mathrm{C}$ as the temperature drops to $18^{\circ} \mathrm{C}$ on the skin surface over the course of the nerve. At the same time, a drop in temperature in the nerve area results in a decrease in the conduction velocity of 1.2 to $2.4 \mathrm{~m} / \mathrm{s} / 1^{\circ} \mathrm{C}$. There are several ways to standardize temperature measurements before nerve conduction tests. One way is to ensure that the skin temperature of the examined limb is $35^{\circ} \mathrm{C}$. The limb can be quickly warmed up (within 1-5 min) by immersion in warm water or the use of a special lamp (the heating time is then even up to $15-20 \mathrm{~min})[2,18,19]$.

Examples of ENG recordings from the median nerve in case of decreased and normal skin temperature of the examined limb are presented in Figures 7 and 8.

\section{Tremor of the examined limb}

Tremor makes it technically difficult to record responses. Interestingly, in one study in patients with polyneuropathy the presence of tremor was found, both in the clinical (59.5\%) and apparatus (74\%) assessments, significantly more often than in the control group (12\%). Tremor in patients with polyneuropathy, irrespective of its aetiology, was most commonly postural (70\%), less frequently resting (51\%) or kinetic (32\%) [20].
Amplituda SNAP jest również odwrotnie proporcjonalna do wzrostu [13].

\section{Grubość skóry}

Grubość skóry jest odwrotnie skorelowana z wielkością odpowiedzi SNAP [16]. U osób o grubszym naskór$\mathrm{ku}, \mathrm{np}$. wykonujących na co dzień ciężką pracę fizyczną, rejestrowane są mniejsze amplitudy SNAP, dlatego konieczne jest częściowe starcie naskórka. Dostępne są $\mathrm{w}$ tym celu specjalne papiery ścierne.

\section{Wiek}

U dzieci szybkość przewodzenia w nerwach jest mniejsza. Wartości takie jak u dorosłych są osiągane u nastolatków. Od 20. roku życia następuje nieznaczne postępujące zmniejszenie szybkości przewodzenia $\mathrm{w}$ nerwach wraz $\mathrm{z}$ wiekiem - o 0,5-1,8 m/s na każde 10 lat $[15,17]$. Spadek szybkości przewodzenia jest bardziej wyraźny w kończynach dolnych niż w górnych [15]. U dorosłych dobrze udokumentowano postępujący wraz z wiekiem spadek amplitudy SNAP, co wynika z utraty włókien czuciowych, a także z powodu zwiększonej dyspersji przewodzenia w nerwach czuciowych. Wydłuża się także czas trwania SNAP [2].

Nie wykazano, aby latencja odpowiedzi we włóknach czuciowych i ruchowych zmieniała się wraz z wiekiem [15].

\section{Temperatura}

Temperatura ma wpływ na pomiary szybkości przewodzenia w nerwach i wielkości odpowiedzi. Wpływa na wielkość odpowiedzi M, SNAP i na szybkość przewodzenia. Amplituda CMAP wzrasta o $1,7 \%$ na $1^{\circ} \mathrm{C}$ wraz ze spadkiem temperatury do $18^{\circ} \mathrm{C}$ na powierzchni skóry nad przebiegiem nerwu. Jednocześnie spadek temperatury w okolicy nerwu powoduje zmniejszenie szybkości przewodzenia od 1,2 do $2,4 \mathrm{~m} / \mathrm{s} / 1^{\circ} \mathrm{C}$. Istnieje kilka sposobów standaryzacji pomiarów temperatury przed badaniami przewodnictwa nerwowego. Jednym $\mathrm{z}$ nich jest zapewnienie temperatury skóry badanej kończyny $35^{\circ} \mathrm{C}$. Kończynę można szybko ogrzać (w czasie 1-5 min) przez zanurzenie w ciepłej wodzie lub za pomocą specjalnej lampy (czas ogrzewania wynosi wówczas nawet do 15-20 $\mathrm{min}$ ) [2, 18, 19].

Przykłady zapisów ENG z nerwu pośrodkowego w przypadku obniżonej i prawidłowej temperatury skóry badanej kończyny przedstawiono na rycinach 7 i 8 .

\section{Drżenie badanej kończyny}

Drżenie utrudnia technicznie rejestrację odpowiedzi. Co ciekawe, w jednym z badań u chorych z polineuropatią stwierdzono obecność drżenia, zarówno w ocenie klinicznej (59,5\%), jak i aparaturowej (74\%), znamiennie częściej niż w grupie kontrolnej (12\%). Drżenie u chorych z polineuropatią, niezależnie od jej etiologii, było najczęściej posturalne (70\%), rzadziej spoczynkowe (51\%) lub kinetyczne (32\%) [20]. 
Factors influencing the result of an electroneurographic examination

Czynniki wpływajace na wynik badania elektroneurograficznego

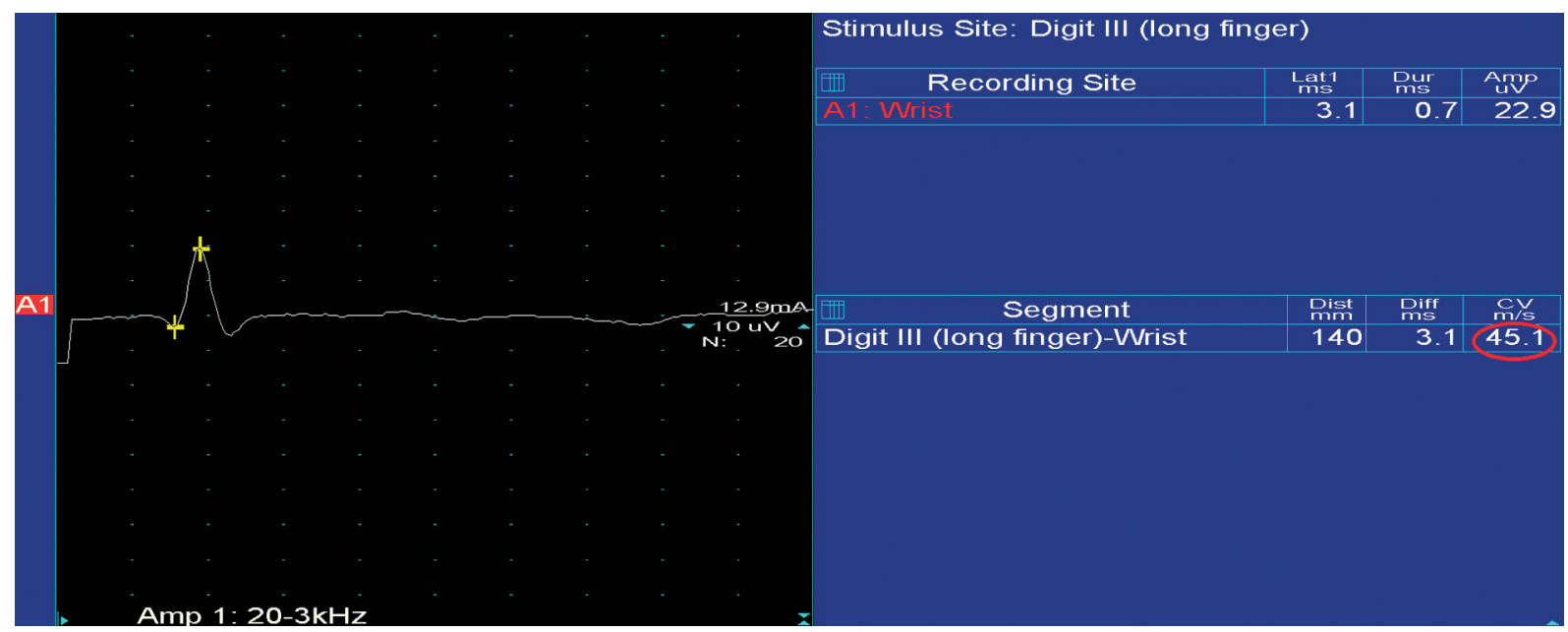

Figure 7. The examination was performed in a patient with a skin temperature of $30^{\circ} \mathrm{C}$ at the site of the median nerve Rycina 7. Badanie wykonano u pacjenta z temperaturą skóry $30^{\circ} \mathrm{C}$ w miejscu przebiegu nerwu pośrodkowego

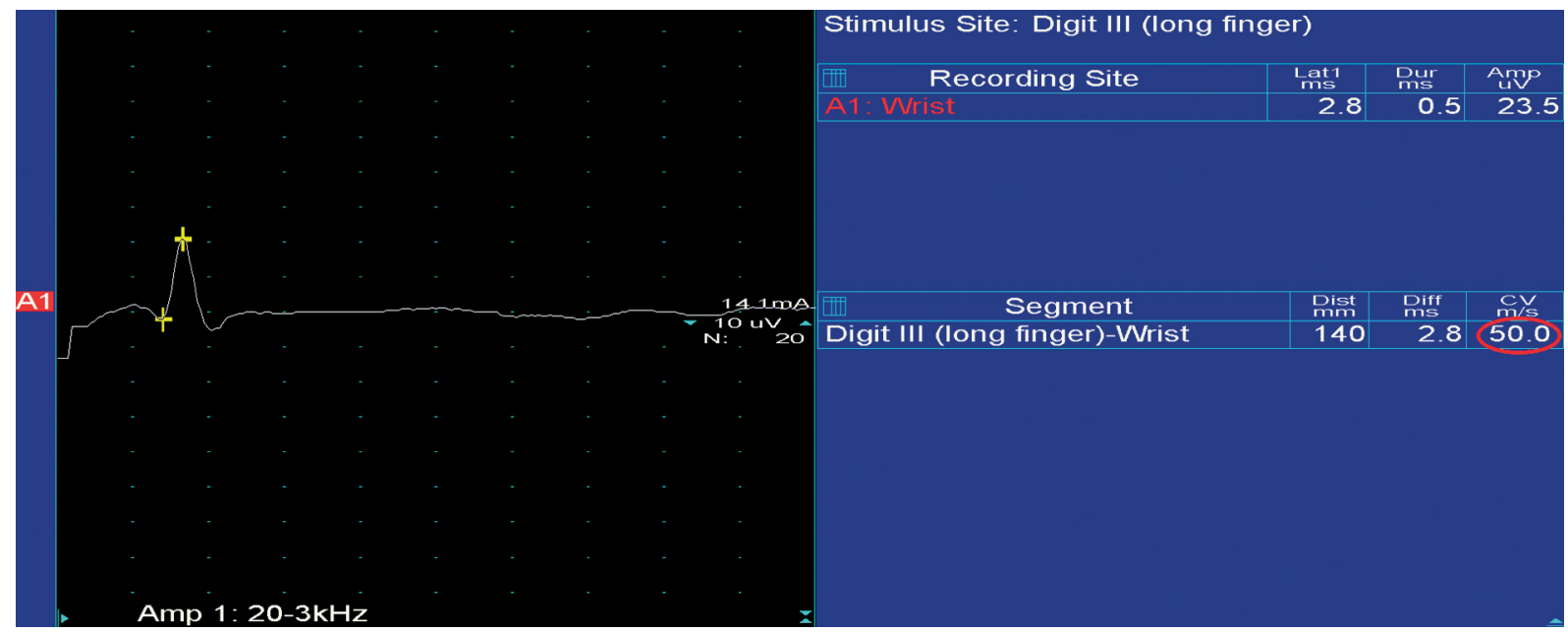

Figure 8. The examination performed in the same patient after heating the skin with a lamp to $34^{\circ} \mathrm{C}$ at the site of the median nerve

Rycina 8. Badanie wykonane u tego samego pacjenta po ogrzaniu skóry za pomocą lampy do $34^{\circ} \mathrm{C}$ w miejscu przebiegu nerwu pośrodkowego

\section{Oedema}

Oedema of the distal lower limbs is a common complication during ENG tests. Oedemas can result in the recording of falsely lowered responses or sometimes the lack of repeatable response, e.g. from the calf nerve. In such cases, it may be helpful to record the response not with surface electrodes (applied to the skin) but with monopolar needle electrodes. Ultrasound navigation for needle electrode insertion may also be helpful [21].

\section{Insufficient number of examined nerves}

To determine whether abnormalities are focal, generalised, distal or proximal, the nerves with long and short

\section{Obrzęk kończyny}

Obrzęki dystalnych odcinków kończyn dolnych są częstym utrudnieniem w trakcie badań ENG. Obrzęki mogą być przyczyną rejestracji fałszywie obniżonych odpowiedzi lub czasem braku powtarzalnej odpowiedzi, np. z nerwu łydkowego. $\mathrm{W}$ takim przypadku pomocne może być rejestrowanie odpowiedzi nie elektrodami powierzchniowymi (naklejanymi na skórę), a monopolarnymi elektrodami igłowymi. Przydatna może być także nawigacja ultrasonograficzna przy wkłuwaniu elektrod igłowych [21].

\section{Niewystarczająca liczba zbadanych nerwów}

W celu ustalenia, czy nieprawidłowości są ogniskowe, uogólnione, zlokalizowane dystalnie lub proksymalnie, 
axons in the upper and lower limbs should be routinely examined. Even with compression neuropathy (e.g. CTS or nerve entrapment), testing should include at least one other nerve that is not suspected to be damaged to rule out a generalized process [1].

We should also mention the anatomical variants of nerves within their course or connections as well as anomalies of innervation. If these variants are not considered, the test conclusions may be incorrect [9]. The Martin-Grubner anastomosis, which is the commonest type of a combination of motor fibres of the ulnar and median nerve on the forearm, deserves a mention here. This anatomical variant occurs in $15-30 \%$ of patients and may affect the ENG test result. In such a case we observe a lower CMAP response amplitude at the wrist level of the median nerve stimulation than the response amplitude obtained at the elbow joint level, or an unusually high rate of conduction in the motor fibres in the median nerve at the forearm. The test result may also be affected by the presence of the additional peroneal nerve. This is a common anatomical variant of the common peroneal nerve innervating the extensor digotorum brevis muscle (EDB), which is usually innervated by the deep peroneal nerve. In $19-22 \%$ of people, however, it can be co-innervated by a branch of the peroneal nerve the superficial peroneal nerve. This variant is inherited in an autosomal dominant way. Its occurrence should be suspected when the amplitude of the EDB response is significantly lower during stimulation of the deep peroneal nerve in the ankle area than that obtained during stimulation in the popliteal region. Typically, the amplitude of the CMAP from the EDB muscle with deep peroneal nerve stimulation in the ankle region is $90-120 \%$ of the response amplitude when stimulated in the popliteal region $[10,11]$.

\section{Limitations of the test}

The ENG test result may be correct in patients with thin fibre neuropathy because the standard test assesses the conduction in thicker, faster-conducting fibres. Heat and pain sensations are, in turn, conducted by the slowest-conducting, thin, unmyelinated fibres [22].

It should be remembered that the abnormalities occurring in the course of nerve damage are detected by the ENG test with some delay. Therefore, the test result may be negative if it is performed too early (e.g. after an injury, compression of the nerve, etc.) and, if necessary, should be repeated approximately 2 weeks later. However, the test should be performed immediately after an injury to rule out nerve rupture, and then again it should be repeated after 2 weeks and 1-3 months later [23, 24]. zwykle należy zbadać nerwy o długich i krótkich aksonach w kończynach górnych i dolnych. Nawet w przypadku neuropatii przebiegającej z uciskiem (np. zespoły cieśni lub uwięźnięcia) badania powinny obejmować co najmniej jeden inny nerw, który nie jest podejrzany o uszkodzenie, aby wykluczyć proces uogólniony [1].

Należy także wspomnieć o wariantach anatomicznych w zakresie przebiegu nerwów, ich połączeń, a także anomalii unerwienia. W przypadku braku uwzględnienia możliwości występowania tych wariantów wnioski z badania mogą być błędne [9]. Na uwagę zasługuje anastomoza Martina-Grubnera, która jest najczęstszym typem połączenia włókien ruchowych nerwu łokciowego i pośrodkowego na przedramieniu. Taki wariant anatomiczny występuje u 15-30\% osób i może wpłynąć na wynik badania ENG. W przypadku istnienia tej anastomozy możemy obserwować niższą amplitudę odpowiedzi M przy stymulacji nerwu pośrodkowego na poziomie nadgarstka od amplitudy odpowiedzi uzyskanej na poziomie stawu łokciowego lub niespotykanie dużą szybkość przewodzenia we włóknach ruchowych w nerwie pośrodkowym na przedramieniu. Na wynik badania może też wpłynąć obecność nerwu strzałkowego dodatkowego. Jest to częsty wariant anatomiczny nerwu strzałkowego wspólnego unerwiający mięsień prostownik wspólny palców (extensor digotorum brevis - EDB). Mięsień ten jest zwykle unerwiany przez nerw strzałkowy głęboki. U 19-22\% osób może być jednak współunerwiony przez gałąź od nerwu strzałkowego - nerw strzałkowy powierzchowny. Ten wariant jest dziedziczony w sposób autosomalny dominujący. Należy podejrzewać jego występowanie, gdy amplituda odpowiedzi znad EDB jest znacząco mniejsza podczas stymulacji nerwu strzałkowego głębokiego w okolicy stawu skokowego, niż uzyskana $\mathrm{w}$ trakcie stymulacji w okolicy dołu podkolanowego. Amplituda odpowiedzi M znad mięśnia EDB przy stymulacji nerwu strzałkowego głębokiego w okolicy stawu skokowego stanowi zwykle 90-120\% amplitudy odpowiedzi przy stymulacji w okolicy dołu podkolanowego $[10,11]$.

\section{Ograniczenia badania}

Wynik badania ENG może być prawidłowy u pacjentów z neuropatią cienkich włókien, gdyż w trakcie standardowego badania ocenia się przewodzenie w grubszych, szybciej przewodzących włóknach. Czucie wysokich temperatur i bólu przewodzone jest $\mathrm{z}$ kolei najwolniej przewodzącymi, cienkimi włóknami bezmielinowymi [22].

Należy pamiętać, że zmiany, które występują w przebiegu uszkodzenia nerwu, znajdują swoje odzwierciedlenie w badaniu ENG z pewnym opóźnieniem. Dlatego też wynik badania może być negatywny, jeśli zostanie wykonane ono zbyt wcześnie (np. po urazie, uciśnięciu nerwu itp.) i powinno $\mathrm{w}$ razie potrzeby być powtórzone po ok. 2 tygodniach. Badanie należy jednak wykonać bezpośrednio po urazie, aby ocenić, czy nie doszło do przerwania ciągłości nerwu, a następnie powinno być powtórzone po 2 tygodniach i 1-3 miesiącach $[23,24]$. 


\section{CONCLUSIONS}

ENG is a valuable tool in the diagnosis of neuromuscular disorders. However, it is an additional test, and when interpreting its results one should always also consider the patient's medical history, physical examination results and results of other tests. There are many factors that may influence the ENG test result and its limitations must always be kept in mind. If the ENG result does not justify the clinical picture, the patient must be re-examined with special care. It must be also considered that other, additional technical factors may affect the test results.

\section{WNIOSKI}

Badanie ENG to cenne narzędzie w diagnostyce zaburzeń nerwowo-mięśniowych. Jest to jednak badanie dodatkowe i interpretując jego wynik, zawsze należy uwzględnić wywiad chorobowy, wyniki badania przedmiotowego i innych badań dodatkowych. Istnieje wiele czynników mogących wpłynąć na wynik badania ENG. Ma ono także pewne ograniczenia, o których należy pamiętać. Jeśli wynik ENG nie uzasadnia obrazu klinicznego, pacjent musi zostać ponownie zbadany z zachowaniem szczególnej staranności. Dodatkowo należy rozważyć możliwość wpływu na wynik badania różnych czynników, w tym technicznych.

\section{Conflict of interest/Konflikt interesu}

Absent./Nie występuje.

Financial support/Finansowanie

Absent./Nie występuje.

\section{References/Piśmiennicłwo}

1. Mallik A, Weir AI. Nerve conduction studies: essentials and pitfalls in practice. J Neurol Neurosurg Psychiatry 2005; 76 Suppl 2: ii23-31.

2. Stålberg E, van Dijk H, Falck B, Kimura J, Neuwirth C, Pitt M, et al. Standards for quantification of EMG and neurography. Clin Neurophysiol 2019; 130: 1688-1729.

3. Tankisi H, Burke D, Cui L, de Carvalho M, Kuwabara S, Nandedkar SD, et al. Standards of instrumentation of EMG. Clin Neurophysiol 2020; 131: 243-258.

4. Goldfarb AR, Saadeh PB, Sander HW. Effect of amplifier gain setting on distal motor latency in normal subjects and CTS patients. Clin Neurophysiol. 2005; 116: 1581-1584.

5. Koo YS, Cho CS, Kim BJ. Pitfalls in using electrophysiological studies to diagnose neuromuscular disorders. J Clin Neurol 2012; 8: 1-14.

6. Pease WS, Pitzer NL. Electronic filter effects on normal motor and sensory nerve conduction tests. Am J Phys Med Rehabil 1990; 69: 28-31.

7. Dumitru D, Zwartz MJ. Instrumentation. In: Dumitru D, Amato AA, Zwarts M (eds.). Electrodiagnostic Medicine. $2^{\text {nd }}$ ed. Philadelphia: Hanley \& Belfus; 2001, p. 69-97.

8. Ven AA, Van Hees JG, Stappaerts KH. Effect of size and pressure of surface recording electrodes on amplitude of sensory nerve action potentials. Muscle Nerve 2004; 30: 234-238.

9. Kimura J. Principles and pitfalls of nerve conduction studies. Ann Neurol 1984; 16(4): 415-429.

10. Preston DC, Shapiro BE. Electromyography and Neuromuscular Disorders. Boston, MA: Butterworth-Heinemann; 1998.

11. Oh SJ. Clinical Electromyography: Nerve conduction studies. $2^{\text {nd }}$ edition. Williams \& Wilkin: 1993.

12. Kowalska B, Sudoł-Szopińska I. Ultrasound assessment on selected peripheral nerve pathologies. Part I: Entrapment neuropathies of the upper limb - excluding carpal tunnel syndrome. J Ultrason 2012; 12: 307-318.

13. Stetson DS, Albers JW, Silverstein BA, Wolfe RA. Effects of age, sex, and anthropometric factors on nerve conduction measures. Muscle Nerve 1992; 15: 1095-1104.

14. Bolton CF, Carter KM. Human sensory nerve compound action potential amplitude: variation with sex and finger circumference. J Neurol Neurosurg Psychiatry 1980; 43: 925-928.

15. Falck B, Andreassen S, Groth T, Lang H, Melander M, Nurmi A, et al. The development of a multicenter database for reference values in clinical neurophysiology - principles and examples. Comput Methods Programs Biomed 1991; 34: 145-162.

16. Hasanzadeh P, Oveisgharan S, Sedighi N, Nafissi S. Effect of skin thickness on sensory nerve action potential amplitude. Clin Neurophysiol 2008; 119: 1824-1828.

17. Awang MS1, Abdullah JM, Abdullah MR, Tharakan J, Prasad A, Husin ZA, et al., Nerve conduction study among healthy malays. The influence of age, height and body mass index on median, ulnar, common peroneal and sural nerves. Malays J Med Sci 2006; 13: 19-23. 
18. Bjorkqvist SE, Lang AH, Falck B, Vuorenniemi R. Variability in nerve conduction velocity. Using averages reduces it, warming of limbs does not. Electromyogr Clin Neurophysiol 1977; 17: 21-28.

19. Moses B, Nelson RM, Nelson AJ Jr, Cheifetz P. The relationship between skin temperature and neuronal characteristics in the median, ulnar and radial nerves of non-impaired individuals. Electromyogr Clin Neurophysiol 2007; 47: 351-360.

20. Wasielewska A, Rudzińska M, Tomaszewski T, Banaszkiewicz K, Wójcik-Pędziwiatr M, Dec-Ćwiek M, et al. Tremor in neuropathies of different origin. Neurol Neurochir Pol 2013; 47: 525-533.

21. Chahl LA, Ladd RJ. Local oedema and general excitation of cutaneous sensory receptors produced by electrical stimulation of the saphenous nerve in the rat. Pain 1976; 2: 25-34.

22. Sène D. Small fiber neuropathy: Diagnosis, causes, and treatment. Joint Bone Spine 2018; 85: 553-559.

23. Chichkova R, Katzin M. EMG and Nerve Conduction Studies in Clinical Practice. 2010. Available at: https:// practicalneurology.com/articles/2010-jan-feb/emg-and-nerve-conduction-studies-in-clinical-practice (Accessed: 20.02.2020).

24. Bergquist ER, Hammert WC. Timing and appropriate use of electrodiagnostic studies. Hand Clin 2013; 29: 363-370. 